\title{
Criminological investigation of loading on a forensic system in Russia
}

\begin{abstract}
Annotation
The article notes that the reduction of the burden on the judicial system in Russia from a technical task has grown into a political-legal one, which cannot be bypassed by scientific attention. Revealing the sources of reducing the burden on the judicial system in Russia, the author reasonably notes that the regulatory order should reflect primarily the public needs of civil society for fair justice and only lastly the workload of Themis figures, the convenience for them of serving justice. Separate sources of reducing the burden on the judicial system in Russia are revealed, their strengths and weaknesses are shown. It is concluded that the question of the sources of reducing the burden on the judicial system in Russia is not an internal matter of the judicial system. This phenomenon should first be considered in terms of ensuring the rights and legitimate interests of citizens.
\end{abstract}

Keywords: justice, the supreme court of Russia, the burden on the judicial system, the sources of reducing the burden on the judicial system in Russia, the public needs of civil society for fair justice, ensuring the rights and legitimate interests of citizens
Volume 7 Issue 5 - 2019

\section{Viktor Grigoriev}

Research Institute, Federal Penitentiary Service of Russia, Russia

Correspondence: Professor Viktor Grigoriev, Doctor of Law, Leading Researcher, Research Institute, Federal Penitentiary Service of Russia, Russia, Email grigorev.viktor@gmail.com

Received: July 13, 2019 | Published: October 23, 2019

\section{Mini review}

The President of the Russian Federation called the workload of the courts one of the most acute problems of the Russian judicial system. "This, of course, affects the quality of judicial acts and can lead a judge to mistakes," said the President, speaking at the XI AllRussian Congress of Judges. The following facts, for example, testify to the enormous loads on Russian judges. According to sociological studies conducted in five federal districts, a fairly large number of judges $(12.4 \%)$ have a standard weekly load of more than 50 cases and materials per week, that is, the judge must decide on 10 cases or materials per day. With an eight-hour working day, this is 48 minutes for one thing. At the same time, the recommended for the marginal rate of the judicial burden on one judge is much lower: for an arbitrator - at the level of 16.8 cases per month; for judges of general jurisdiction - at the level of 2.8 criminal cases or 5 civil cases per week. In this regard, reducing the burden on the judicial system is a very urgent task of the modern stage of its development. Reducing the burden on the judicial system as a whole and on individual judges in particular seems to be an important but rather technical measure. That is why it does not appear in research as a direction for reforming the judicial system in Russia. Meanwhile, almost all of the legislative activity of the Supreme Court of the Russian Federation, ${ }^{1}$ which has been very active in recent years, has this orientation. And from technical this direction has grown into a political-legal one, which cannot be ignored.

Reducing the burden is not an internal matter of the judicial system. ${ }^{2}$ This phenomenon should first be considered in terms of ensuring the rights and legitimate interests of citizens. Therefore, reducing the burden should primarily meet the interests of Russian citizens. It should be recognized that the legal and regulatory framework should reflect, first of all, the social needs of civil society in a fair justice, and only last of all the workload of the leaders of Themis, the convenience for them of the form of serving justice.
As the analysis shows, among the sources of reducing the burden on the judicial system in Russia can be:

1) Improvement of courts.

2) Exclusion from the judicial sphere of indisputable procedures not related to disputes and conflicts.

3) Limited access to justice.

4) Rejection of the principles and norms guaranteeing the protection of the rights and legitimate interests of citizens.

Not all of these sources look progressive and democratic. In this regard, I note that they do not represent a kind of official program and, moreover, full practical implementation. Some of them are seen only as a barely catchable trend, others are generally hypothetical. But it is precisely because of the ambiguity of their assessment that they need to be considered and determined (approved or denied) as sources of reducing the burden on the judicial system.

\section{Improving the activities of courts as a source of reducing the burden on the judicial system in Russia}

A very significant source of reducing the burden on the judicial system in Russia is the improvement of judicial clerical work, the introduction of electronic forms of criminal, civil, arbitration and administrative cases, the introduction of electronic evidence, distance technologies, block chain technologies into the process of proof. At the present stage in the judicial system of the Russian Federation, the State Automated System "Justice" is applied. The main task of the Justice system is the implementation of comprehensive automation of all functional and ensuring tasks confronting the courts of general jurisdiction, the bodies of the judicial community, the Judicial Department at the Supreme Court of the Russian Federation. ${ }^{3}$ The system provides solutions for such tasks as: automating the workplaces 
of judges and court employees, maintaining audio recordings of court sessions, providing access to electronic databases and legal information systems, informing citizens about court activities, publishing information on pending cases and court decisions on Internet sites. The introduction of modern electronic technologies in the judicial system of the Russian Federation has significantly increased the level of public access to justice, improving its quality and at the same time reducing the time it takes to try cases in court, creating conditions for all members of the legal community and mass media to quickly receive information about the activities of the courts. ${ }^{4}$

Along with there, not all innovations in this direction cause unconditional approval. We are talking about, for example, such a measure to reduce the burden on judges, which is offered by the Supreme Court of the Russian Federation, to abandon the practice of writing the reasoning part of a decision in civil and arbitration cases. The press gives an unexpectedly clever argument for the failure of such a line of development of procedural form and correctly noted that such innovations "are designed based on the misunderstood purpose of procedural legislation, which is not to simplify and simplify the life of the judiciary, but to effectively resolve disputes about the law".

Exclusion from the judicial sphere of indisputable procedures and legal resolution of disputes without the participation of the court as a source of reducing the burden on the judicial system in Russia

One of the variants of this source of reducing the burden on the judicial system in Russia is, for example, an attempt to get rid of "indisputable" insurance claims. The need to reduce the number of subrogation cases several times, that is, the obligation to reimburse the amount paid in direct damages (this situation arises when one company sells the CTP insurance policy and another company makes payments to the car owner), is justified. Arbitrage receives many small subrogation claims. For the plaintiffs, this is a way to get compensation in full, for defendants to pull time or to defend their position in court. Moreover, in most cases, representatives of the parties in such disputes do not even appear at court hearings. Meanwhile, the majority of such claims are "indisputable", that is, the court only checks the validity of mathematical calculations between insurance companies according to the Unified Methodology for Determining the Amount of Expenses for Refurbishment Repair approved by the Russian Union of Motor Insurers. It is obligatory for application by all insurers who, in principle, can carry out these calculations independently, without shifting the responsibility for this onto the shoulders of judges. Another option for this source of reducing the burden on the judicial system in Russia is the institution of mediation. It contributes to the unloading of the judicial system and the system for the enforcement of court decisions, which occurs: due to the actual settlement of disputes through the mediation procedure (some of the disputes currently before the courts could be resolved through pre-trial or extrajudicial mediation, for example, small claims - the so-called "small claims"; in the case of a settlement of a dispute through a mediation procedure, after going to court and accepting a claim, there is no need to conduct a trial and decide on the merits of the dispute, to form the reasoning part; by preventing future disputes in the future between the same parties;

due to the fact that most decisions taken as a result of the mediation procedure are executed by the parties voluntarily and are not contested in the future; thus, the rulings made by the court after the dispute has been resolved using the mediation procedure will not be appealed to a higher court.

\section{Restricting access to justice as a source of reducing the burden on the judicial system in Russia}

Liquidation of instances and procedures that allow citizens to realize their claims in court, of course will inevitably entail a reduction in the burden on the judicial system. However, this will simultaneously lead to an increase in the demand for illegal means of resolving disputes and conflicts. Most importantly, in my opinion, this will give rise to social tensions with the prospect of revolutionary forms of its release. Because of this, this trend is undesirable among the sources of reducing the burden on the judicial system in Russia. One could not have talked about this if it were not for the initiatives of the Supreme Court of the Russian Federation, which are partly evaluated in just this way. "According to some experts, the proposals of the Supreme Court are necessary and positive, but others believe that the amendments mainly reflect the desire of judges to " make their lives easier at the expense of litigants "by complicating access to the court and reducing procedural guarantees."

\section{Waiver of principles and norms guaranteeing the protection of the rights and legitimate interests of citizens as a source of reducing the burden on the judicial system in Russia}

Today, processes that manifest themselves in total attempts to simplify the work of the criminal justice authorities began to predominate in the development of a special criminal procedure form. As a result, it is possible to observe how modern trends ${ }^{5}$ are formed in the simplification of the procedural form, which received the generalized name of optimization.

In modern Russian criminal proceedings, the optimization came in the form of a special procedure for court proceedings with the consent of the person with the accusation against him (Chapter 40 of the Code of Criminal Procedure of the Russian Federation). Then this procedure was extended to cases with a pre-trial agreement on cooperation (Chapter 40.1 of the Code of Criminal Procedure) and cases investigated by way of shortened inquiries (Chapter 32 of the Code of Criminal Procedure of the Russian Federation).

The most recent trends in procedural form reflect the needs of servants of Themis ${ }^{6}$ in order to facilitate their work, to make it easier and less burdensome, convenient for solving everyday issues. The presented assessments of the development of Russian criminal justice are consonant with the fact that they were made public on March 2, 2017 in the Supreme Court of the Russian Federation at a scientific-practical conference on the topic "Criminal and criminal procedure legislation of Russia: the main problems of application and areas for improvement". At this conference, in particular, it sounded that "because of the instability, imbalance and inconsistency of the existing substantive and procedural norms, it becomes increasingly difficult for judges to ensure that trials are conducted, to evaluate evidence, to make court decisions, a number of other problems arise. All this happens, including because the legislator, as we think, does not clearly know which way to go, what rules to follow when forming the legal basis for combating crime and does not always relate the acts adopted to the goals of the rule of law and constitutional values". ${ }^{7-12}$ 
The easy way to solve the problems of criminal justice is certainly attractive. However, it has long been noted that cheap justice is expensive. In my opinion, the transfer of justice to the base of recognition of the accused guilty - not the historical experience, to the modern implementation of which efforts should be made. Tendencies towards simplification of the criminal procedure form must be opposed by the desire to apply it adequately, economically. To this end, actions that do not meet the criteria of public danger should be promptly eliminated from its sphere, and transferred to the sphere of administrative jurisdiction. Modern special proceedings based on the guilty plea of the accused and implying a refusal on this basis to establish the actual circumstances of the crime in court should be audited and assessed for compliance with the demands and state of modern civil society in Russia.

Paying attention to the special proceedings that have been multiplying in recent years, based on pleading guilty to the accused and suggesting a refusal to establish the actual circumstances of the crime in court, I would like to express an alternative view on the future development of Russian criminal justice. The obvious fact that these proceedings contradict the Constitution of the Russian Federation requires that they be subjected to revisions and an assessment of compliance with the demands and the state of modern civil society in Russia. Alternative solutions are proposed to solve the problem of the exhaustion of traditional resources for the further development of criminal justice. ${ }^{13}$ These resources should be sought not in curtailing the constitutional rights of citizens, but in the computerization of criminal proceedings, the development of options for introducing blockchain technologies into it. In general, it can be concluded that the question of the sources of reducing the burden on the judicial system in Russia is not an internal matter of the judicial system. This phenomenon should first of all be considered from the point of view of ensuring the rights and legitimate interests of citizens, meeting the social needs of civil society in a fair justice.

\section{Acknowledgments}

None.

\section{Conflicts of interest}

The author declares there are no conflicts of interest.

\section{References}

1. Berseneva T. The Supreme Court is preparing a reform. 2017.

2. Bratishcheva A. Reduce the burden: will amendments to the law on OSAGO reduce the number of insurance disputes. 2017.

3. Vladimir Putin took part in the work of the IX All-Russian Congress of Judges.

4. Information technology in the courts of Russia.

5. Grigoriev V.N. An Alternative View of Some Modern Trends in the Criminal Procedure Form. 2017.

6. Grigoriev V.N. Themis in search of a convenient form (on some current trends in the development of the criminal procedure form). 2015.

7. Komarov A.S. The main ways of development of the Russian judicial system and the Supreme Court of the Russian Federation: problems and prospects for reform. Rostov scientific journal. 2017.

8. The concept of judicial reform and the main directions of transformation of the judicial system in the Russian Federation.

9. Mediation in the judicial system: Collected materials. 2017.

10. Scientific-practical conference. Criminal and criminal procedure legislation of Russia: the main problems of application and directions for improvement. 2019.

11. On the reform of the Supreme Court. 2017.

12. Orobets V.M. The main directions of the reform of the judicial system in the Russian Federation.

13. Zenovina V. According to the scientific community, in Russia it is necessary to adopt the concept of development of criminal policy. 2017. 